Article

\title{
Improvement of the Enzyme Performance of Trypsin via Adsorption in Mesoporous Silica SBA-15: Hydrolysis of BAPNA
}

\author{
Shanshan Li ${ }^{1,2, \dagger}$, Zhuofu Wu ${ }^{1,3, \dagger}$, Ming Lu ${ }^{1}$, Zhi Wang ${ }^{1}$ and Zhengqiang Li ${ }^{1}{ }^{1} *$
}

1 Key Laboratory for Molecular Enzymology and Engineering of the Ministry of Education, College of Life Sciences, Jilin University, Changchun 130012, China

College of Life Sciences and Agriculture and Forestry, Qiqihar University, Qiqihar 161006, China

3 State Key Laboratory of Inorganic Synthesis and Preparative Chemistry, College of Chemistry, Jilin University, Changchun 130012, China

$\dagger$ These authors contributed equally to this work.

* Author to whom correspondence should be addressed; E-Mail: lzq@jlu.edu.cn; Tel./Fax: +86-431-8515-5201.

Received: 3 December 2012; in revised form: 9 January 2013 / Accepted: 10 January 2013 / Published: 16 January 2013

\begin{abstract}
The enzymatic performance of trypsin in hydrolysis of $N$ - $\alpha$-benzoyl-DLarginine-4-nitroanilide (BAPNA) was improved by adsorption on Santa Barbara Amorphous (SBA)-15 mesoporous silica. The optimal immobilization conditions were screened and the properties of immobilized enzyme have also been studied. Under the optimal conditions, the immobilized trypsin displays maximum specific activity $(49.8 \mu \mathrm{mol} / \mathrm{min} / \mathrm{g})$. The results also indicate that the immobilized trypsin exhibits better storage stability.
\end{abstract}

Keywords: SBA-15 mesoporous silica; trypsin; immobilization; specific activity; hydrolysis; BAPNA

\section{Introduction}

The technique of enzyme immobilization plays an important role in modern biotechnology [1]. It can not only stabilize the quaternary structure of enzymes [2,3], but also maintain or enhance enzyme activity in comparison to the free enzyme [4,5]. 
During the last decades, the mesoporous silica has become the perfect carrier due to its tailorable pore size in the range 2 30 nm, high special surface area and strong adsorption capability [6]. The enzymes immobilized on mesoporous silica shows perfect stabilization and excellent reusability in catalytic reactions as compared to free enzymes. After grafting with the acid, basic, hydrophilic or hydrophobic group, functionalized mesoporous molecule sieves yielded new characteristics which enhanced the affinity between the silica matrix and the enzyme and induced an increase of the specific activity [7]. So far, mesoporous molecule sieves have already been used to immobilize many enzymes [8,9]. Undoubtedly, physical adsorption was one of the simplest, the mildest and the most effective methods of enzyme immobilization, compared with other methods such as encapsulation, or covalent attachment [10] and many reports have focused on enzyme adsorption on ordered mesoporous silica [11-13].

SBA-15 mesoporous silica possesses thick uniform silica walls (3.1 to $6.4 \mathrm{~nm}$ ) as compared to the other mesoporous silicas such as MCM-41 or MCM-48, which provides SBA-15 with better stability. Hence, many researchers have studied the applications of this material. In 2008, the adsorption of penicillin acylase was performed using amino-functionalized mesoporous silica SBA-15 [14]. The immobilized PGA enzyme retained its activity without significant loss after the ten cycles. Yin et al. investigated the adsorption of lysozyme on mesoporous SBA-15 rods with tunable pore length [15]. Monduzzi and coworker synthesized mesoporous silica SBA-15 and used it as a support for the immobilization of lipase by physical and chemical adsorption [16]. The lysozyme adsorption kinetics on SBA-15 could be described according to a pseudo-second order model or an intraparticle diffusion model [17]. Owing to Kim and colleges' report, the pore expander SBA-15 was used to adsorb the bovine carbonic anhydrase for $\mathrm{CO}_{2}$ sequestration [18]. Cheng et al. demonstrated that the short-channel SBA-15-p materials provided higher adsorption capacities and adsorption rates with cytochrome c compared to conventional fiber-like SBA-15 materials [19]. According to the report of Tan and colleagues, lipase was adsorbed into aminopropyl-grafted mesoporous silica nanotubes to achieve the resolution of $(R, S)$-1-phenylethanol [20]. Immobilized lipase on aminopropyl-grafted mesoporous silica nanotubes acquired higher activity than immobilized lipase on mesoporous silica nanotubes owing to the reformation of secondary structure of lipase after the immobilization. In Tumbiolo's report, pepsin was immobilized in mesoporous silica SBA-15 by physical adsorption. The pore openings of the mesoporous silica SBA-15 was reduced by grafting organosilane groups to minimize the leaching of pepsin [21]. It can be concluded that SBA-15 is a perfect carrier for enzyme immobilization.

However, poor results were obtained when SBA-15 was used as carrier to immobilize trypsin [22]. The main problem is the rapid autolysis of trypsin, which may severely decrease the performance of the immobilization trypsin. Addition of some stabilizing agents can overcome this problem. Michael has reported that use of a CD-containing polymer as an additive could improve the functional stability of trypsin in aqueous solutions [23]. They found that trypsin was 6-fold more resistant to autolytic inactivation in the presence of the additive. Moreover, trypsin was chemically modified by derivatives of cyclodextrin, and the increased resistance of CD-trypsin conjugates to autolysis and temperature was observed [24,25]. In this manuscript, the trypsin was adsorbed into SBA-15 with $\beta$-cyclodextrin as stabilizing agents. Immobilization conditions were screened and the properties of immobilized enzyme have also been evaluated. 


\section{Results and Discussion}

\subsection{Synthesis and Characteristic of SBA-15 Mesoporous Silica}

The small-angle X-ray pattern shows three well-resolved peaks indexed to (100), (110), and (200) reflections corresponding to a two-dimensional hexagonal $P 6 \mathrm{~mm}$ structure with a large unit-cell parameter (Figure 1) [26]. The nitrogen adsorption-desorption isotherm at $77 \mathrm{~K}$ (Figure 2) can be classified as type IV and exhibits an $\mathrm{H}_{1}$-type hysteresis at high relative pressure [27]. These were typical features of mesoporous silica SBA-15. $\mathrm{H}_{1}$ hysteresis reveals the presence of open channels which facilitates the effective diffusion of substrates and product. It is well known that the size matching between enzyme molecular and host matrix pore plays a key role in achieving high enzyme loadings [11]. As shown in the inset of Figure 2, the narrow Barrett-Joyner-Halenda (BJH) distribution of the synthesized SBA-15 is $63 \AA$, which is appropriate for the adsorption of trypsin (it's spherical diameter is about $3.8 \mathrm{~nm}$ ) [28].

Figure 1. Powder XRD pattern of mesoporous silica SBA-15.

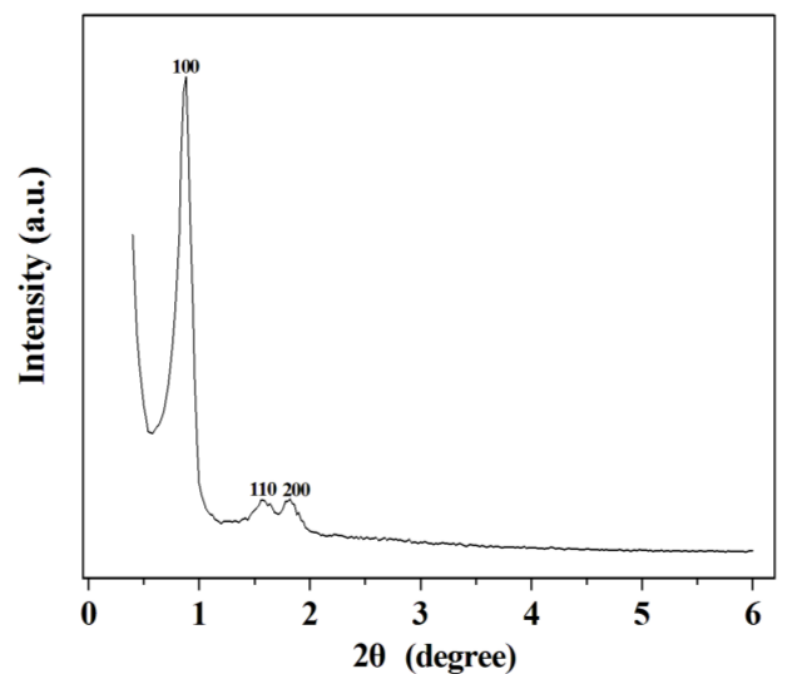

Figure 2. Nitrogen adsorption-desorption isotherms and BJH pore size distributions of mesoporous silica SBA-15: adsorption curve $(\boldsymbol{\square})$ and desorption curve $(\bigcirc)$.

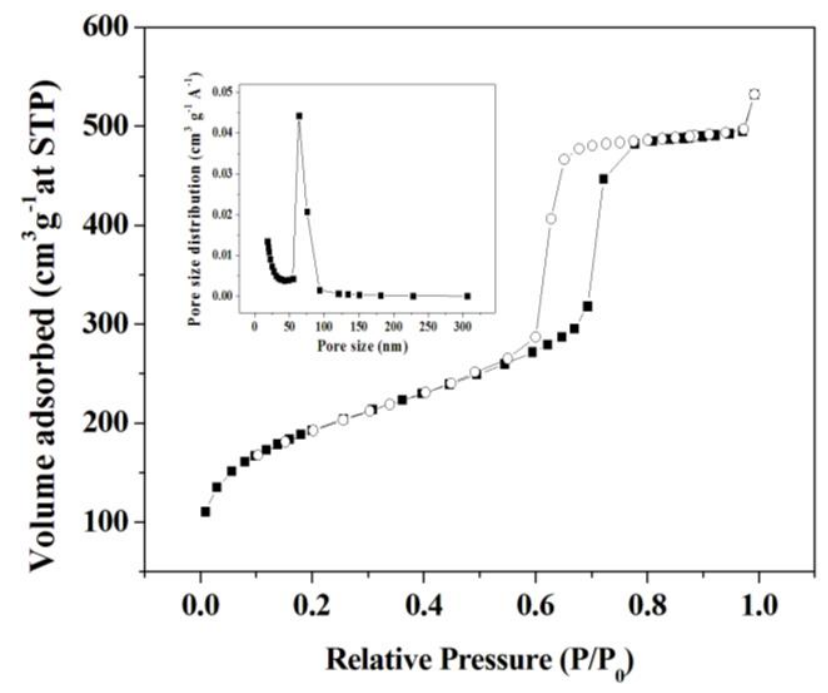




\subsection{Influence of Immobilization Conditions on Trypsin Activity}

\subsubsection{Effect of Immobilization $\mathrm{pH}$}

The charge state of protein and mesoporous silica SBA-15 can be modulated by changing pH value of the solution, which can alter the electrostatic forces between mesoporous silica SBA-15 and trypsin. To clarify the influence of $\mathrm{pH}$ of the immobilization solution on immobilization process, the specific activity of the immobilized trypsin prepared was detected in different $\mathrm{pH}$ solutions. As shown in Figure 3, the specific activity gradually increases in the $\mathrm{pH}$ range of 2.5 7.0, and decreased sharply from $\mathrm{pH} 7.0$ to 10.0. The maximum specific activity was observed at $\mathrm{pH} 7.0$. It's known that the isoelectric points of mesoporous silica SBA-15 and the trypsin are 2.1 [6] and 10.5 [11], respectively. When the immobilization process was carried out in the solution with the $\mathrm{pH}$ in the range of 2.5 10.0, the opposite charges of mesoporous silica SBA-15 and trypsin were beneficial for the adsorption. However, the denaturation of enzyme caused by low $\mathrm{pH}(2.5 \sim 6.0)$ or high $\mathrm{pH}$ (8.0 10.0) decreases the specific activity of immobilized trypsin.

Figure 3. Effect of $\mathrm{pH}$ on the specific activity of immobilized trypsin.

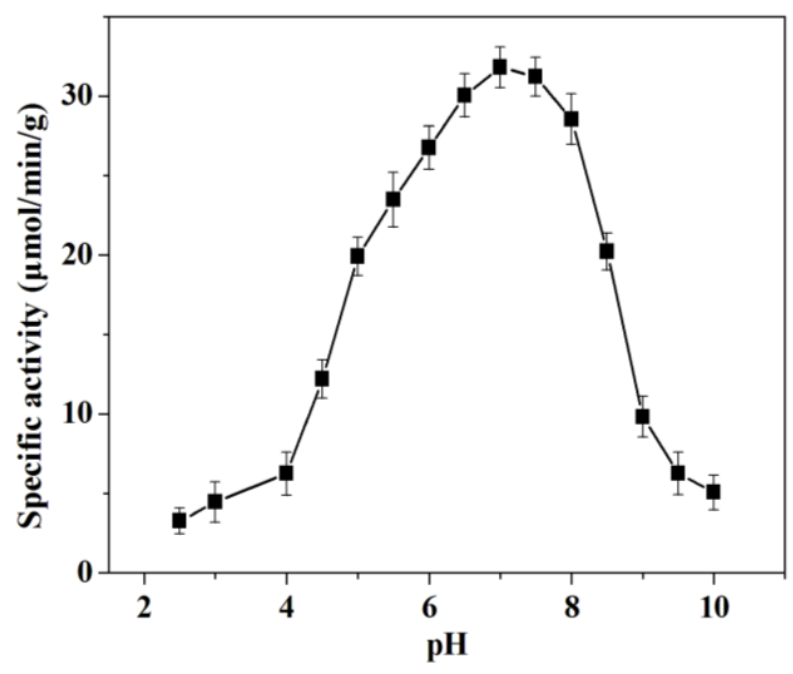

\subsubsection{Effect of the Ratio of Trypsin to $\beta$-Cyclodextrin}

It's well known that the lyophilization during immobilization involves inherent destabilization forces that can denature the enzyme e.g., cold shock, ice-water interfaces, dehydration stress, etc. [29], so in this study, $\beta$-cyclodextrin was selected as lyoprotectant to protect trypsin during immobilization. The effect of the ratio of trypsin to $\beta$-cyclodextrin has been investigated in the range from 1:0.5 to 1:4 $(\mathrm{w} / \mathrm{w})$ and the results are shown in Figure 4. The maximum specific activity was obtained at the ratio 1:1.5 (w/w). The effect of additives on the activity of immobilized trypsin is not yet well understood. It's generally believed that the presence of $\beta$-cyclodextrin during the immobilization process can give protection to trypsin against the damage from lyophilization [30,31]. Furthermore, $\beta$-cyclodextrin might decrease the autolysis of the trypsin during the immobilization process [23]. However, $\beta$-cyclodextrin at high concentrations could destroy the electrostatic attraction between trypsin and mesoporous silica SBA-15, which led to the decrease of adsorbed amount. 
Figure 4. Effect of the ratio of trypsin to $\beta$-cyclodextrin on the specific activity of immobilized trypsin.

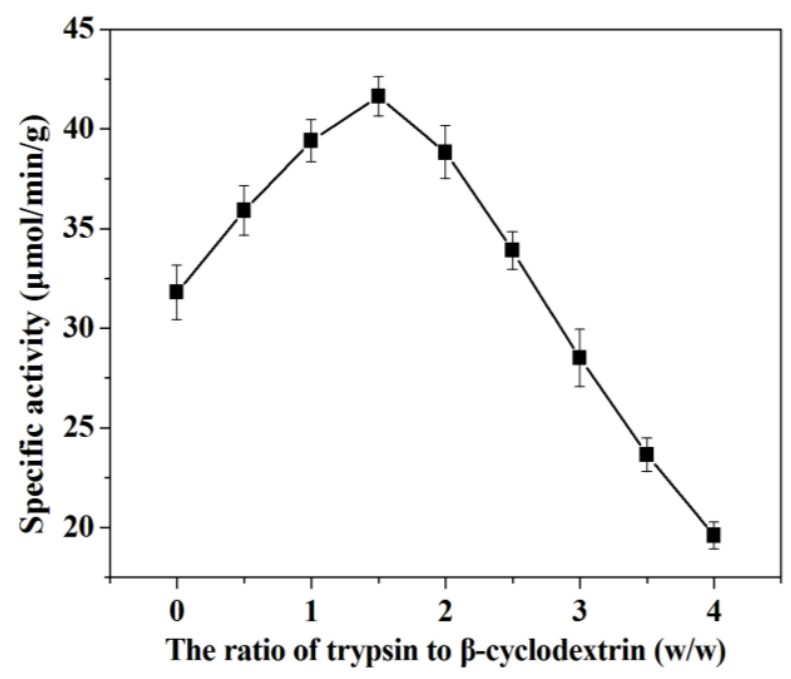

\subsubsection{Effect of Immobilization Time}

The effect of immobilization time on the enzyme activity was studied in the range of $0.1 \sim 22 \mathrm{~h}$. It can be observed from Figure 5 that the enzyme activity exhibits a bell shaped curve with changing immobilization time and the maximum enzyme activity was observed at $4 \mathrm{~h}$. In this study, the initial trypsin amount used was beyond the adsorption capability of mesoporous silica SBA-15. The specific activity of immobilized trypsin increases with the extension of immobilization time at the initial stage (0-4 h), which might mainly be due to the increase in trypsin loading amount. The specific activity of trypsin approaches the maximum value at an immobilization time of $4 \mathrm{~h}$, suggesting that the monolayer adsorption of trypsin reached its saturation point. When the immobilization time was too long, the over-loading of trypsin could lead to a multi-layered stacking of enzyme, which would block the substrate molecules from accessing to the internal trypsins and thus decreased the enzyme activity. Such a result is consistent with a published report in which the multilayer adsorption of lipase caused the decreased of enzyme activity [32]. Moreover, the self-hydrolysis of trypsin became more and more serious with the increase of immobilization time. This result is in accordance with Lei's report in which the specific activity of entrapped glucose oxidase in mesoporous silica decreased with increasing protein loading density [33].

\subsection{Enzyme Performance of the Immobilized Trypsin}

\subsubsection{Reusability}

Generally speaking, the enzymes dissolved in reaction medium are often difficult to recover, let alone reuse. Therefore, the reusability of immobilized enzyme deserves further research. To check this parameter, the immobilized trypsin was used in subsequent cycles for the hydrolysis of BAPNA. As seen in Figure 6, the enzyme activity of adsorbed trypsin decreases slightly as the number of recycles increases. After seven cycles, the adsorbed trypsin still retains $42 \%$ of initial activity. The lost of enzyme activity shall be mainly attributed to the leaching of adsorbed trypsin at the repeated reaction, 
separation and rinsing steps in successive reaction owing to the weak electrostatic interaction between trypsin and mesoporous silica SBA-15. Furthermore, the leached trypsin increases the possibility of the autolysis.

Figure 5. Effect of immobilization time on the specific activity of immobilized trypsin.

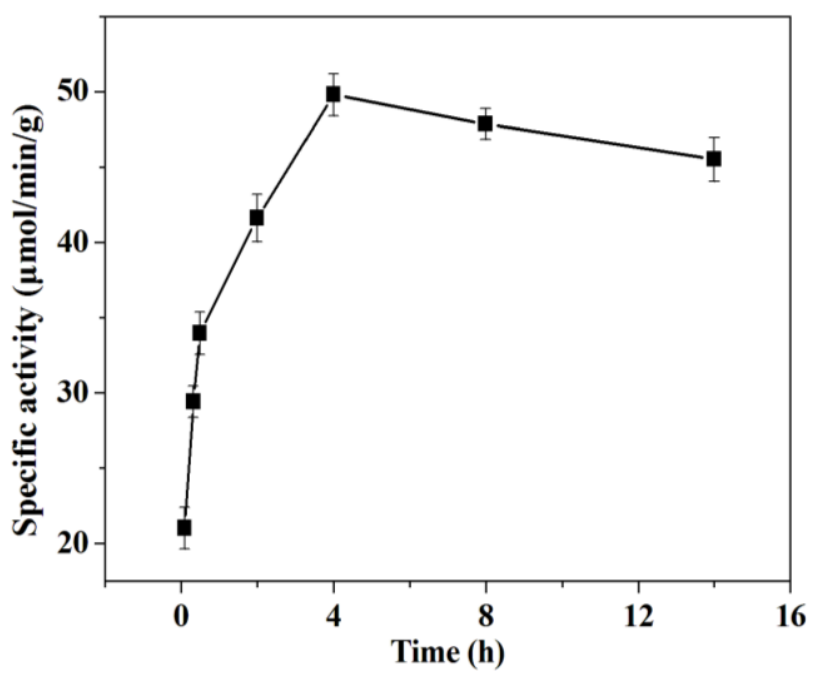

Figure 6. Catalyst recycling of the immobilized trypsin. The specific activity of immobilized trypsin $\left(49.8 \mu \mathrm{mol} \mathrm{min}^{-1} \mathrm{~g}^{-1}\right)$ in the first cycle was taken as control (100\%).

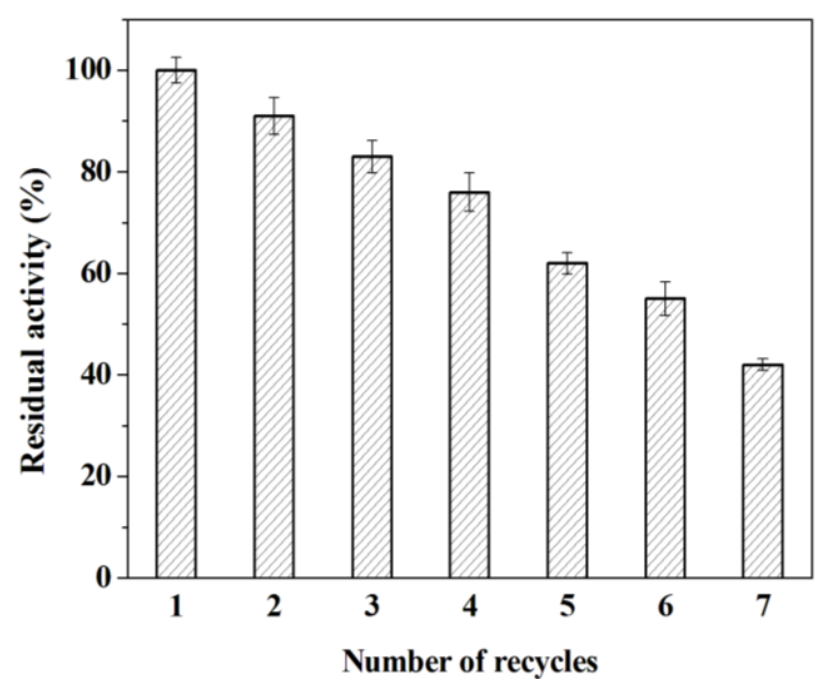

\subsubsection{Storage Stability}

The storage stability of immobilized and free enzyme was investigated at $4{ }^{\circ} \mathrm{C}$ for 3 weeks. Figure 7 presents that the adsorbed trypsin conserved $64 \%$ of initial activity, whereas the free trypsin maintained $44 \%$ of initial activity in 21 days. 
Figure 7. Storage stability of the immobilized $(\square)$ and free trypsin $(\bullet)$. For free trypsin,

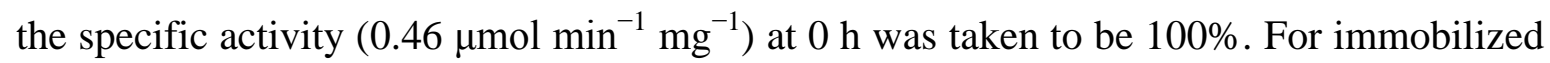

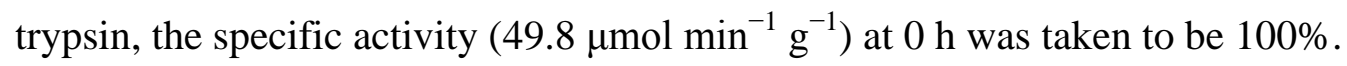

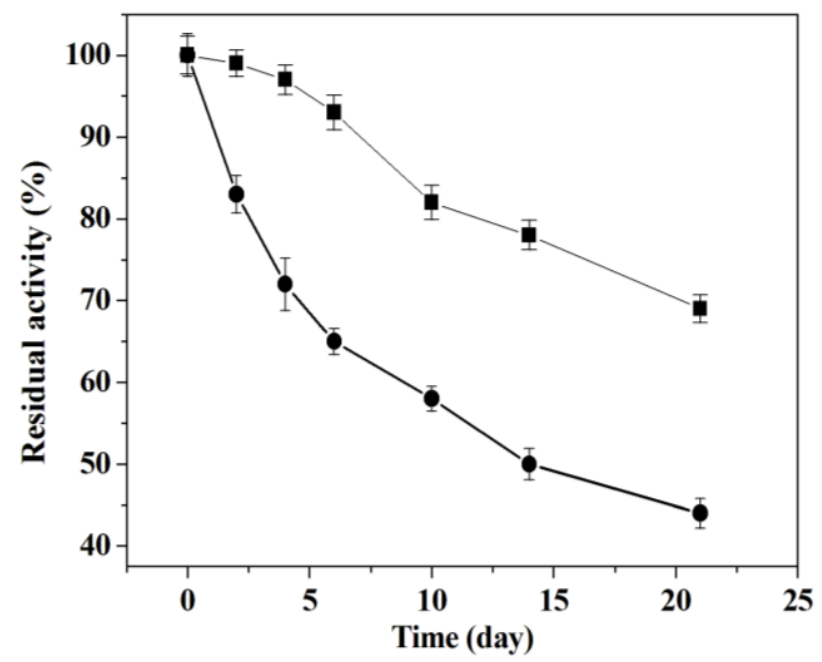

This enhanced stability was due to the inhibition of autolysis after adsorption. After immobilization, the positively charged trypsin can be tightly attached to the negatively charged silica wall, and then the collision between entrapped trypsins is restricted, which lowered the autolysis of the trypsin. However, unlike the anchoring bonds of covalently attached enzymes, lowered electrostatic interaction between adsorbed trypsin and mesoporous silica SBA-15 leads to the leakage of the trypsin and weakens the storage stability. Bein and coworker had immobilized trypsin in the channel of large-pore SBA-15 by a click chemistry approach and verified that no trypsin leaching was found after immobilization [34]. In Jasra's work, alkaline serine endopeptidase was immobilized on surface-modified SBA-15 through amide bond formation by using carbodiimide as a coupling agent and it was demonstrated that immobilized enzymes showed higher specific activity than the free enzyme, which was ascribed to easy accessibility of substrate molecules to active sites of immobilized enzyme [35]. In order to improve the reusability and storage stability of immobilized trypsin, the trypsin immobilization by covalent attachment method is being worked on and will be published in due course.

\section{Experimental}

\subsection{Materials}

TEOS and Pluronic P123 (EO20-PO70-EO20, MW = 5800) were commercially available from Sigma-Aldrich (St. Louis, MO, USA). Trypsin from the bovine pancreas (EC 3.4.21.4) and BAPNA were also obtained from Sigma-Aldrich. $\beta$-Cyclodextrin and all other reagents were of analytical grade. All aqueous solutions were prepared with Milli-Q water.

\subsection{The Synthesis of Mesoporous Molecular Sieve}

P123 (0.8 g) was dissolved in distilled water (25 mL). Then $\mathrm{HCl}(12 \mathrm{M}, 3 \mathrm{~mL})$ and TEOS (2.4 g) were added. The system was stirred for $24 \mathrm{~h}$ at $40{ }^{\circ} \mathrm{C}$, followed by crystallization for $48 \mathrm{~h}$ at $100{ }^{\circ} \mathrm{C}$ in the reaction kettle. After calcination at $550{ }^{\circ} \mathrm{C}$ for $5 \mathrm{~h}$, the template in mesoporous silica SBA-15 was 
removed. The mesoporous structure of mesoporous silica SBA-15 was characterized by X-ray powder diffraction (XRD, Siemens, D5005, Karlsruhe, Germany) pattern using nitrogen as balance air and hydrogen as carrier air. The specific surface area was assessed through the Brunauer-Emmett-Teller (BET) method, and the pore size distribution curve was computed using the Barrett-Joyner-Halenda (BJH) method (ASAP 2010M, Micromeritics Inc., Norcross, GA, USA).

\subsection{Preparation the Immobilization Solution}

Trypsin ( $1 \mathrm{~g}$ ) was dissolved in $\mathrm{K}_{2} \mathrm{HPO}_{4}-\mathrm{KH}_{2} \mathrm{PO}_{4}$ buffer $(100 \mathrm{~mL}, \mathrm{pH} 7.0,0.05 \mathrm{M}$, ) and the insoluble impurity was removed by centrifugation $(8,000 \mathrm{rpm}, 5 \mathrm{~min})$ at $4{ }^{\circ} \mathrm{C}$. Finally the supernatant was lyophilized. The immobilization solution $[10 \mathrm{mg} / \mathrm{mL}$ of trypsin, containing $\beta$-cyclodextrin $(15 \mathrm{mg} / \mathrm{mL})]$ was prepared by redissolving the lyophilized trypsin in the $\mathrm{K}_{2} \mathrm{HPO}_{4}-\mathrm{KH}_{2} \mathrm{PO}_{4}(\mathrm{pH} 7.0$, $0.05 \mathrm{M})$ buffer at $4{ }^{\circ} \mathrm{C}$.

\subsection{The Preparation of Adsorbed Trypsin}

The aliquot of mesoporous silica SBA-15 solid powders $(1 \mathrm{~g})$ was immersed in immobilization solution $(100 \mathrm{~mL})$ for $4 \mathrm{~h}$ with stirring at $4{ }^{\circ} \mathrm{C}$. After centrifugation at $4,000 \mathrm{rpm}$ for $7 \mathrm{~min}$, the resulting product was repeatedly washed by the buffer with the same $\mathrm{pH}$, until the UV absorbance $(280 \mathrm{~nm})$ in the supernatant disappeared. Finally, the resultant sample was lyophilized, and then stored at $-20{ }^{\circ} \mathrm{C}$. The final product was white powder.

\subsection{Optimization of the Immobilization Process}

The whole procedure of adsorption was implemented at $4{ }^{\circ} \mathrm{C}$ to reduce the inactivation and autolysis of trypsin.

\subsubsection{Optimization of Immobilization $\mathrm{pH}$}

The buffers with different $\mathrm{pH}$ value $(2.5 \sim 10.0)$ were used to optimize the $\mathrm{pH}$ during immobilization process at $4{ }^{\circ} \mathrm{C}$. The used buffers were citric acid-sodium citrate $(\mathrm{pH} 2.5-4.6), \mathrm{K}_{2} \mathrm{HPO}_{4}-\mathrm{KH}_{2} \mathrm{PO}_{4}$ ( $\mathrm{pH}$ 5.8-8.0) and Gly-NaOH (pH 9.3-10.0), respectively. The specific activity of the immobilized trypsin was assayed according to the description in Section 3.6.

\subsubsection{Optimization of the Ratio of Trypsin to $\beta$-Cyclodextrin}

The adsorption process of trypsin was carried out in $\mathrm{K}_{2} \mathrm{HPO}_{4}-\mathrm{KH}_{2} \mathrm{PO}_{4}$ buffer at $4{ }^{\circ} \mathrm{C}(\mathrm{pH} 7.0$, containing different amount of $\beta$-cyclodextrin). After lyophilization, the specific activity of the immobilized trypsin was measured following the procedure in Section 3.6.

\subsubsection{Optimization of Immobilization Time}

The mesoporous silica SBA-15 solid powders $(1 \mathrm{~g})$ were immersed into trypsin solution $(100 \mathrm{~mL})$ for different immobilization times $(0.1 \sim 22 \mathrm{~h})$ at $4{ }^{\circ} \mathrm{C}$. Then the specific activity of the immobilized trypsin was measured following the procedure in Section 3.6. 


\subsection{Enzyme Activity Assay}

The enzyme activity of trypsin was measured using BAPNA as substrate. The reaction system contained BAPNA $(100 \mu \mathrm{L}, 10 \mathrm{mM})$ and $\mathrm{K}_{2} \mathrm{HPO}_{4}-\mathrm{KH}_{2} \mathrm{PO}_{4}$ buffer $(800 \mu \mathrm{L}, 0.05 \mathrm{M}, \mathrm{pH} 7.0)$. The hydrolytic reaction was triggered by adding the enzyme $(5 \mathrm{mg})$. Then, the reaction mixture was incubated in water bath at $25^{\circ} \mathrm{C}$ for 5 min with magnetic stirring. Thereafter, the reaction was stopped by adding $30 \%$ acetic acid solution $(0.5 \mathrm{~mL})$ followed by centrifuging at $12,000 \mathrm{rpm}$ for $3 \mathrm{~min}$. The amount of $p$-nitroaniline produced was determined at $410 \mathrm{~nm}$. The specific activity $(\mu \mathrm{mol} / \mathrm{g} / \mathrm{min})$ was defined as the amount (in micromoles) of $p$-nitroaniline produced per minute per gram of SBA-15 loaded with the trypsin.

\subsection{Reusability}

The immobilized trypsin was used for successive batches. The relative activity of adsorbed trypsin was measured according to the assay described in Section 3.6. After each cycle, the reaction mixture was centrifuged at 12,000 rpm for $3 \mathrm{~min}$. The obtained precipitation was washed with $\mathrm{K}_{2} \mathrm{HPO}_{4}-\mathrm{KH}_{2} \mathrm{PO}_{4}$ buffer $(\mathrm{pH} 7.0,0.05 \mathrm{M})$ to remove any residual substrate or product and then kept overnight in a vacuum oven for a complete drying. After the centrifugation, washing and drying, the powder was used at next cycle under otherwise equivalent conditions. The residual activity of the recycled enzyme was compared with the enzyme activity of the first cycle (100\%).

\subsection{Assessment of Storage Stability}

The immobilized trypsin was kept in $\mathrm{K}_{2} \mathrm{HPO}_{4}-\mathrm{KH}_{2} \mathrm{PO}_{4}$ buffer ( $\mathrm{pH} 7.0,0.05 \mathrm{M}$ ) at $4{ }^{\circ} \mathrm{C}$ for 21 days. With BAPNA as substrate, the residual activity was checked from time to time according to the description in Section 3.6. The relative activity of immobilized trypsin at specific storage time was compared with the enzyme activity of immobilized trypsin before storage (100\%). For free trypsin, the storage stability was measured according to above mentioned process.

\subsection{Statistical Analysis}

The data expressed in various studies was plotted using Sigma Plot-9 and expressed as standard error $( \pm)$. Each value represents the mean for three independent experiments performed in duplicate, with average standard deviation $<5 \%$.

\section{Conclusions}

In this manuscript, trypsin was immobilized in mesoporous silica SBA-15 by physical adsorption to obtain optimal specific activity for the hydrolysis of BAPNA. When the immobilization of trypsin had been performed in $\mathrm{pH} 7.0$ buffers for $4 \mathrm{~h}$ and the ratio of trypsin to $\beta$-cyclodextrin was 1.5 in the adsorption system, the optimal enzyme activity was obtained. Under the optimum conditions, the native conformation of trypsin is retained and the overlay or aggregation between the immobilized enzyme molecules is maximally avoided. Most importantly, $\beta$-cyclodextrin provided protection for trypsin during the immobilization process. After seven recycles, immobilized trypsin maintains $42 \%$ of 
initial activity, and the loss of enzyme activity is mainly due to the leakage of the enzyme. During 30 days, the immobilized trypsin exhibits better storage stability than the free one, which is attributed to the protection from the hydroxyls of $\beta$-cyclodextrin and SBA-15 mesoporous silica. On the basis of this work, the protective effect of additive (polyol) on enzyme immobilization and stabilization in mesoporous silica material will be investigated, particularly in non-conventional media. In future work, the resultant immobilized trypsin will be used to synthesize amino acid esters in organic media.

\section{Acknowledgments}

This work was financially supported by the National High Technology Research and Development Program of China (2006AA02Z232), Social Development Research Project of Science and Technology Department of Jilin Province (20090404) and Doctoral Fund of Ministry of Education of China (20100061110028).

\section{Conflict of Interest}

The authors declare no conflict of interest.

\section{References}

1. Cao, L.; Langen, L.V.; Sheldon, R.A. Immobilised enzymes: Carrier-bound or carrier-free? Curr. Opin. Chem. Biol. 2003, 14, 387-394.

2. Fernández-Lafuente, R.; Rodríguez, V.; Mateo, C.; Penzol, G.; Hernández-Justiz, O.; Irazoqui, G.; Villarino, A.; Ovsejevi, K.; Batista, F.; Guisán, J.M. Stabilization of multimeric enzymes via immobilization and post-immobilization techniques. J. Mol. Catal. B Enzym. 1999, 7, 181-189.

3. Bernal, C.; Sierra, L.; Mesa, M. Improvement of thermal stability of $\beta$-galactosidase from Bacillus circulans by multipoint covalent immobilization in hierarchical macro-mesoporous silica. J. Mol. Catal. B Enzym. 2012, 84, 166-172.

4. Wu, Z.; Dong, M.; Lu, M.; Li, Z. Encapsulation of $\beta$-galactosidase from Aspergillus oryzae based on "fish-in-net" approach with molecular imprinting technique. J. Mol. Catal. B Enzym. 2010, 63, $75-80$.

5. Masuda, Y.; Kugimiya, S.-I.; Murai, K.; Hayashi, A.; Kato, K. Enhancement of activity and stability of the formaldehyde dehydrogenase by immobilizing onto phenyl-functionalized mesoporous silica. Colloid. Surfaces B 2013, 101, 26-33.

6. Zhao, D.; Huo, Q.; Feng, J.; Chmelka, B.F.; Stucky, G.D. Nonionic Triblock and Star Diblock Copolymer and Oligomeric Surfactant Syntheses of Highly Ordered, Hydrothermally Stable, Mesoporous Silica Structures. J. Am. Chem. Soc. 1998, 120, 6024-6036.

7. Jang, S.; Kim, D.; Choi, J.; Row, K.; Ahn, W. Trypsin immobilization on mesoporous silica with or without thiol functionalization. J. Porous Mater. 2006, 13, 385-391.

8. Yang, X.Y.; Li, Z.Q.; Liu, B.; Klein-Hofmann, A.; Tian, G.; Feng, Y.F.; Ding, Y.; Su, D.S.; Xiao, F.S. "Fish-in-Net" Encapsulation of Enzymes in Macroporous Cages for Stable, Reusable, and Active Heterogeneous Biocatalysts. Adv. Mater. 2006, 18, 410-414. 
9. Liu, J.; Guan, J.; Lu, M.; Kan, Q.; Li, Z. Hemoglobin immobilized with modified "fish-in-net" approach for the catalytic removal of aniline. J. Hazard. Mater. 2012, 217-218, 156-163.

10. Chouyyok, W.; Panpranot, J.; Thanachayanant, C.; Prichanont, S. Effects of $\mathrm{pH}$ and pore characters of mesoporous silicas on horseradish peroxidase immobilization. J. Mol. Catal. B Enzym. 2009, 56, 246-252.

11. Díaz, J.F.; Balkus, K.J., Jr. Enzyme immobilization in MCM-41 molecular sieve. J. Mol. Catal. B Enzym. 1996, 2, 115-126.

12. Lu, S.; An, Z.; Li, J.; He, J. pH-Triggered Adsorption-Desorption of Enzyme in Mesoporous Host to Act on Macrosubstrate. J. Phys. Chem. B 2011, 115, 13695-13700.

13. Yasutaka, K.; Takato, Y.; Takashi, K.; Kohsuke, M.; Hiromi, Y. Enhancement in Adsorption and Catalytic Activity of Enzymes Immobilized on Phosphorus- and Calcium-Modified MCM-41. J. Phys. Chem. B 2011, 115, 10335-10345.

14. Shah, P.; Sridevi, N.; Prabhune, A.; Ramaswamy, V. Structural features of Penicillin acylase adsorption on APTES functionalized SBA-15. Micropor. Mexopor. Mat. 2008, 116, 157-165.

15. Ding, Y.; Yin, G.; Liao, X.; Huang, Z.; Chen, X.; Yao, Y.; Li, J. A convenient route to synthesize SBA-15 rods with tunable pore length for lysozyme adsorption. Micropor. Mesopor. Mat. 2013, 170, 45-51.

16. Salis, A.; Meloni, D.; Ligas, S.; Casula, M.F.; Monduzzi, M.; Solinas, V.; Dumitriu, E. Physical and Chemical Adsorption of Mucor javanicus Lipase on SBA-15 Mesoporous Silica. Synthesis, Structural Characterization, and Activity Performance. Langmuir 2005, 21, 5511-5516.

17. Steri, D.; Monduzzi, M.; Salis, A. Ionic Strength Affects Lysozyme Adsorption and Release from SBA-15 Mesoporous Silica. Micropor. Mesopor. Mat. 2013, 170, 164-172.

18. Vinoba, M.; Kim, D.H.; Lim, K.S.; Jeong, S.K.; Lee, S.W.; Alagar, M. Biomimetic Sequestration of $\mathrm{CO} 2$ and Reformation to $\mathrm{CaCO} 3$ Using Bovine Carbonic Anhydrase Immobilized on SBA-15. Energ. Fuel. 2010, 25, 438-445.

19. Chen, S.-Y.; Chen, Y.-T.; Lee, J.-J.; Cheng, S. Tuning pore diameter of platelet SBA-15 materials with short mesochannels for enzyme adsorption. J. Mater. Chem. 2011, 21, 5693-5703.

20. Bai, W.; Yang, Y.-J.; Tao, X.; Chen, J.-F.; Tan, T.-W. Immobilization of lipase on aminopropylgrafted mesoporous silica nanotubes for the resolution of (R, S)-1-phenylethanol. J. Mol. Catal. B Enzym. 2012, 76, 82-88.

21. Manyar, H.G.; Gianotti, E.; Sakamoto, Y.; Terasaki, O.; Coluccia, S.; Tumbiolo, S. Active Biocatalysts Based on Pepsin Immobilized in Mesoporous SBA-15. J. Phys. Chem. C. 2008, 112, 18110-18116.

22. Yiu, H.H.P.; Wright, P.A.; Botting, N.P. Enzyme immobilisation using SBA-15 mesoporous molecular sieves with functionalised surfaces. J. Mol. Catal. B Enzym. 2001, 15, 81-92.

23. Fernández, M.; Villalonga, M.L.; Caballero, J.; Fragoso, A.; Cao, R.; Villalonga, R. Effects of $\beta$-cyclodextrin-dextran polymer on stability properties of trypsin. Biotechnol. Bioeng. 2003, 83, 743-747.

24. Fernández, M.; Fragoso, A.; Cao, R.; Baños, M.; Villalonga, R. Chemical conjugation of trypsin with monoamine derivatives of cyclodextrins: Catalytic and stability properties. Enzyme Microb. Technol. 2002, 31, 543-548. 
25. Fernández, M.; Fragoso, A.; Cao, R.; Baños, M.; Ansorge-Schumacher, M.; Hartmeier, W.; Villalonga, R. Functional properties and application in peptide synthesis of trypsin modified with cyclodextrin-containing dicarboxylic acids. J. Mol. Catal. B Enzym. 2004, 31, 47-52.

26. Zhao, D.; Feng, J.; Huo, Q.; Melosh, N.; Fredrickson, G.H.; Chmelka, B.F.; Stucky, G.D. Triblock copolymer syntheses of mesoporous silica with periodic 50 to 300 angstrom pores. Science 1998, 279, 548-552.

27. Tompsett, G.; Krogh, L.; Griffin, D.; Conner, W. Hysteresis and scanning behavior of mesoporous molecular sieves. Langmuir 2005, 21, 8214-8225.

28. Goradia, D.; Cooney, J.; Hodnett, B.K.; Magner, E. The adsorption characteristics, activity and stability of trypsin onto mesoporous silicates. J. Mol. Catal. B Enzym. 2005, 32, 231-239.

29. Kadoya, S.; Fujii, K.; Izutsu, K.-I.; Yonemochi, E.; Terada, K.; Yomota, C.; Kawanishi, T. Freeze-drying of proteins with glass-forming oligosaccharide-derived sugar alcohols. Int. J. Pharm. 2010, 389, 107-113.

30. Santagapita, P.R.; Brizuela, L.G.; Mazzobre, M.F.; Ramirez, H.L.; Corti, H.R.; Santana, R.V.; Buera, M.P. Structure/Function Relationships of Several Biopolymers as Related to Invertase Stability in Dehydrated Systems. Biomacromolecules 2008, 9, 741-747.

31. Santagapita, P.R.; Brizuela, L.G.; Mazzobre, M.F.; Ramírez, H.L.; Corti, H.R.; Santana, R.V.; Buera, M.P. $\beta$-Cyclodextrin modifications as related to enzyme stability in dehydrated systems: Supramolecular transitions and molecular interactions. Carbohyd. Polym. 2011, 83, 203-209.

32. Li, Y.; Zhou, G.; Li, C.; Qin, D.; Qiao, W.; Chu, B. Adsorption and catalytic activity of Porcine pancreatic lipase on rod-like SBA-15 mesoporous material. Colloids Surf. A Physicochem. Eng. Asp. 2009, 341, 79-85.

33. Lei, C.; Soares, T.A.; Shin, Y.; Liu, J.; Ackerman, E.J. Enzyme specific activity in functionalized nanoporous supports. Nanotechnology 2008, 19, 125102-125111.

34. Schlossbauer, A.; Schaffert, D.; Kecht, J.; Wagner, E.; Bein, T. Click Chemistry for High-Density Biofunctionalization of Mesoporous Silica. J. Am. Chem. Soc. 2008, 130, 12558-12559.

35. Kannan, K.; Jasra, R.V. Immobilization of alkaline serine endopeptidase from Bacillus licheniformis on SBA-15 and MCF by surface covalent binding. J. Mol. Catal. B Enzym. 2009, 56, $34-40$.

Sample Availability: Samples of the immobilized trypsin are available from the authors.

(C) 2013 by the authors; licensee MDPI, Basel, Switzerland. This article is an open access article distributed under the terms and conditions of the Creative Commons Attribution license (http://creativecommons.org/licenses/by/3.0/). 